\title{
Batik Standardization as Batik Artisan Empowerment Model For Marketing Process
}

\author{
Muslichah Erma Widiana ${ }^{1} \quad$ Karsam $^{2} \quad$ Kusni Hidayati ${ }^{3}$ \\ 1.School of Business and Economic, Bhayangkara University, Surabaya, Indonesia \\ 2.School of Creative Industry, Dinamika University, Surabaya, Indonesia \\ 3.School of Economic Development, Bhayangkara University, Surabaya, Indonesia
}

\begin{abstract}
The purpose of this study is to produce batik standardization as an empowerment model addressed to batik ARTISAN as individuals, and / or business entities for the marketing / trading process. This was triggered by the existence of the ASEAN free market in 2015 which resulted in the deccreasing of Indonesian batik marketing; there were lots of Indonesians who do not know the quality of Batik Cloth; lack of supervision by the Indonesian government of sales behavior; the shortcome of Indonesia Trade Law. The problem in this research is how to make The Model of Batik Standardization for the empowerment of Batik ARTISAN marketing, either individuals, and / or business entities. In order to solve this problem the method used is descriptive qualitative method and direct practice. Data was obtained through observation in the field / direct practice), in-depth observations, and literature studies and internet sources. The results of this study are that every batik cloth sold must be labeled "batikINDONESIA", Indonesian government supervision of the marketing process should be carried out continuously, hence; there should be a control and enforcement of Indonesia's trade law. This research is expected to produce a batik standardization model for marketing empowerment so that batik ARTISAN in Indonesia, both as individuals, and / or business entities can carry out batik production and marketing smoothly.
\end{abstract}

Keywords: SNI Batik, Standardization, Marketing

DOI: $10.7176 / \mathrm{EJBM} / 12-27-05$

Publication date:September $30^{\text {th }} 2020$

\section{Introduction}

The aim to be achieved in this research is to produce batik standardization as an empowerment model for batik ARTISAN, either as individuals, or business entities for the marketing/trading process. This was triggered by many things, such as; 1) there was ASEAN free market in 2015 , batik cloth from abroad easily circulated in Indonesian market which resulted in a decreasing of Indonesian batik marketing; 2) Most of Indonesian do not know the quality of batik cloth, either know or do not know the standardization of batik cloth (SNI), so they buy batik cloth only based on its visual; 3) Lack of supervision by the Indonesian government on sales behavior; 4) there were many shortcomings in The Republic of Indonesia's Trade Law.

Nurmayanti (2014) explained that entrepreneurs said that the Trade Law was still lacking. Bambang Sujagat, the chairperson of the Chamber of Commerce and Industry (Kadin) in the Industrial field, Research and Technology, assesses that there are lots of things which must be adjusted by the government in the trade law, because it cannot facilitate entrepreneur's desires. For an instance: Indonesia National Standard (SNI), Trade law should not only issue free trade, but also issue fair trade.

Bambang Sujagat has also explained about Indonesia National Standard (SNI). According to Bambang, The Government is not ready to implement SNI as mandatory for all national products. Bambang has expressed his critics towards the government. He has stated that the government has provided threats towards the entreprenurs. For example: the entrepreneur will be considered commit crime, if he does not follow SNI. Criminal sanctions will be given to CEO of company, whereas the CEO is not always the owner of a company. The CEO only follows the owner's wish. In addition, the Trade Law should provide protection for local Entrepreneurs, especially in dealing with the ASEAN free market or international trade. The government should be able to create not only fair trade but also free trade. Moreover; trade behavior within the Indonesian state must also be regulated.

Trade law in Indonesia should be able to imitate the trade law applied in neighboring countries, for an instance, Malaysia; The price of $1 \mathrm{~kg}$ rice is set by the Government of Malaysia for about RM 5 ( 5 Malaysian Ringgit). This price applies to all stores. Those who sell more than $5 \mathrm{RM}$ per $1 \mathrm{~kg}$ of rice across will be cancelled their trading business lincense (SIUP). The researcher (Karsam) learned this law during his stay in Malaysia from 1995-2005.

The trade law in Malaysia has not been applied yet well in Indonesia, so that there was an unhealthy marketing process. Moreover, the presence of ASEAN / international free market makes the foreign-made goods get in Indonesia easily and eventually becomes a threat to domestic products.

\footnotetext{
${ }^{1}$ Economics and Business Faculty, University of Bayangkara Surabaya

${ }^{2}$ D4 Film and Television Production, Dinamika University, Surabaya-Indonesia

${ }^{3}$ Ekonmics dan Business Faculty, University of Bayangkara Surabaya
} 
Karsam (2019: 39) explained that while being a batik training instructor at the Community Activity Unit (UKM) in East Java province (2015-2018), batik artisans have begun to complain as their batik sales have begun to decrease (not sold well). This is due to the entry of foreign batik cloth into Indonesia such as; China, India, Malaysia, and others. Foreign batik cloth is sold freely in Indonesian market. Many of Public as buyers / consumers do not know whether it is batik cloth or is it just a motif cloth? What they know is a Printed cloth with beautiful colors and the price is relatively cheap. Especially about what Batik Tulis is? What a Batik cap is? What Batik Kombinasi is? They generally do not know. This is the main factor in the market decreasing of Batik in batik marketing.

Apart from those factors above, there are several other factors which are the cause of failure in marketing, including the presence of:

1. Products which cannot satisfy consumers

2. slow-moving products (unchanged)

3. Erratic purchasing patterns

4. The changing of organization and marketing techniques

5. Improper attitude and style / model of marketing management

6. Competition is increasing both domestically and abroad and it is not healthy.

As a result of the failure in marketing mentioned above, causing:

1. Items sold are not sold nicely

2. Goods sold are less attractive to consumers

3. Companies can lose the consumer's trust

4. The company could suffer from losses.

5. The development of the company is disrupted.

Based on the description above, it is considered necessary to have standardization. Therefore, a problem of this research was formulated, namely how to make batik a standardization model for marketing empowerment for either individual batik artisans or business entities.

Imam Fahrudin (2018) explained that standardization is an attempt to determine a measurement that must be followed in producing something. Standardization can be interpreted as the process of making standards. BSN (2014) explained that the root word of standard comes from the standard root of the word standardization, which is translated into Indonesian into standarisasi. The word standard comes from French, namely: norme and etalon. The word norme can be interpreted as a standard of document form. Etalon is defined as an ISIS standard or measurement standard. While the term standardization has the meaning of a unit of measurement that can be used as a basis in comparing among real quantity, quality, value, and work. One of the benefits of standardization is that groups can communicate easily in accordance with predetermined guidelines to stay focused. Standardization in Indonesia is issued by the National Standardization Agency (BSN). At the international level standardization is known as the International Organization for Standardization (ISO).

The purpose of using standardization, namely:

1. Developing, supplying, and manufacturing a product and service can be cleaner, safer, more efficient and more qualified.

2. Being a guideline for environmental legislation, safety in health, equality, and so on.

3. Accelerating the processing time for products or services which are innovative in entering the market.

4. Providing the best and fairer facilities in interstate trade.

5. Making people's lives more comfortable, peaceful, and simple because every problem is overcome together.

6. Joining the technology development and practicing about good and right management.

7. Ensuring a guarantee on general or consumer use regarding products and services.

Along withi this standardization, it is expected that marketing management can run smoothly.

Marketing is a social process. The occurrence of a trade relationship by creating and maintaining products and values between individuals and groups to get what they need. Marketing can also be interpreted as a business system by planning, pricing, promoting and distributing goods and services to satisfy consumers.

Rai Utama (2017: 237-239) explained that marketing management is a tool for analyzing, planning, implementing, and controlling programs designed to build, create, and generate intended exchanges with a view to achieve the company's goals in reaching profit.

Marketing management is an activity carried out by the company to maintain the company, so that it continues growing and generates a profit. The marketing process begins before goods are produced and do not end in sales. Marketing activities are carried out by the company in order to provide satisfaction to consumers, so that the business keeps continuing. To keep running the business smoothly, the marketing strategy is needed.

Widiana (2019: 1) explained that the marketing strategy was seen as a general statement about the direction or guidelines in choosing a target market and designing and applying a mix marketing. Three main aspects are covered, namely:

1. Company determines the market (where to compete). 
2. Business in developing products and services (on what basis to compete).

3. Punctuality to enter the market and market development activities (when to compete).

While in marketing there are several things that must be considered, namely:

1. Target market or market oriented.

2. Marketing must be held in an integrated manner.

3. Meet customer satisfaction.

4. Always maintain the quality of the product or service.

Keep maintaining product quality is the main thing that must be done, so that the marketing process runs well.

Sonalia (2013) explained the quality or product quality is part of quality management carried out at each stage of the process, beginning with product line planning and infrastructure or facilities until monitoring results. Quality management has functions in the marketing process, such as; human resource management, finance and so on. The implementation of quality management must be applied in all industrial sectors, including industrial manufacture. Industrial manufacture is a type of business group that processes raw materials for intermediate or finished goods that have a low / small value to become higher.

In Indonesia, the manufacturing industry strives to continue developing in order to compete in the era of free competition. At least, this industry can survive in product development, so it can be exported abroad. One example of small industrial clothing like leather and other products which are very interesting to be developed is batik industry product.

Karsam (2019: 3) explained that before batik was recognized by UNESCO as a humanitarian heritage for the oral and non-cultural culture of the Indonesian nation on 2 October 2009, the word batik had various meanings. Based on existing regulations, which are in accordance with the Indonesian National Standard (SNI) 08-02391989, what is meant by batik is the textile cloth staining according to the typical patterns of Indonesian batik patterns, using batik wax as a barrier. SNI contains an explanation about batik cloth will be considered meet Indonesia National Standard if the cloth is not damaged or perforated. This fact is different from the condition of batik cloth in Kerek District, Tuban Regency, where this condition can lead to a new definition of batik.

After batik has been recognized by UNESCO, Indonesian batik artisans, practitioners, and academicians continue developing batik. The author in 2017-2018 conducted a study in Kerek District, Tuban Regency, about the Gedhog batik Cocohan technique (Bramantijo, 2019). From the results of this study, it formulated a new definition of batik. What is meant by batik is a textile cloth staining according to the typical patterns of Indonesian batik, by using batik wax as a barrier and or picking a hole to produce a color. Whereas, the batik technique received SNI approval was explained by Karsam (2019: 187-197), namely: based on the technique and batikmark "Indonesian batik", batik was divided into:

1. Batik Tulis

Batik Tulis is a batik obtained by using canting as an auxiliary tool to attach batik wax to the cloth. Batikmark label for batik as shown in picture 1. The writing label is yellow gold.

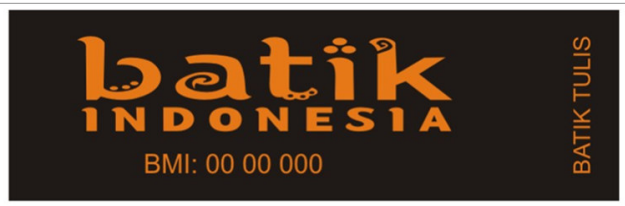

Picture 1. Label batikmark Batik Tulis

2. Batik cap (Source: Karsam, 2019: 190)

Batik cap is a batik obtained by using batik stamp of copper as an auxiliary tool to attach batik wax to the cloth. Batikmark label for batik stamp as shown in picture 2.

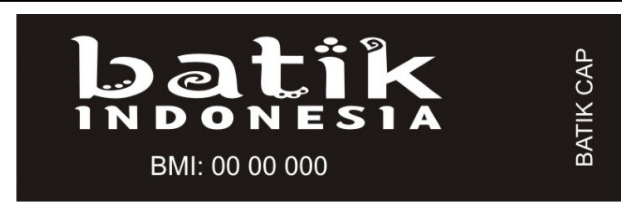

Picture 2. Lable batikmark Batik Cap

(Source: Karsam, 2019: 191)

3. Batik Kombinasi Batik Kombinas is a batik combination between Batik Tulis and Batik cap. A Batik Kombinas is a batik gained
by using both canting and Batik cap from copper as an auxiliary tool to attach batik wax to the cloth. Batikmark labels for Batik Kombinas as shown in picture 3. Silver Label Writing. 


\section{logtik BMl: 0000000}

Picture 3. Lable batikmark Batik Kombinasi

(Source: Karsam, 2019: 191)

Batik SNI is also explained in the Decree of the Head of the Indonesian Standardization Agency Number: 188/KEP/ 8/2016 concerning Establishment of Revision of 3 (three) Indonesian National Standards, namely: 1. SNI 8302: 2016, cloth-feature Batik Tulis, quality requirements, and test method.

2. SNI 8303: 2016, cloth-feature Batik cap, quality requirements, and test method.

3. SNI 8304: 2016, cloth-feature Batik Kombinas, quality requirements, and test method.

SNI Number: 188/KEP/8/2016 clarifies in detail about the characteristics of Batik Tulis, Batik cap, and Batik Kombinas. It is clarified by the Centre for Crafts and Batik (2017) on How to distinguish Printed Cloths and Batik Cloth?

After fulfilling SNI "batik-INDONESIA" other efforts which should be done by batik artisans as either individuals or business entities to keep marketing going on is the effort to preserve and develop batik itself(Karsam, 2014). One of the forms of batik preservation and development is to make new motifs which are adjusted towards market needs. In order to avoid the problem arises, the motifs must be protected by copyright (HKI). The seizure of the copyright of the 2 companies happened in 2020 conveyed by Jawa Pos Newspaper. Each of them admitted that they were the one who design it.

Karsam (2019: 210) explained that what is meant by Copyright is the exclusive right of the creator that arises automatically based on a declarative principle after a work is realized in real form without reducing restrictions in accordance with statutory provisions (Law of the Republic of Indonesia Number 28 of 2014 concerning HKI). HKI can also be defined as a legal protection given by the State to a person and / or group of people or bodies whose ideas have been set forth in the form of a copyrighted work (tangible).

Copyrighted works or creations are any creations in the field of science, art, and literature that are produced on inspiration, abilities, thoughts, imagination, dexterity, skills, or expertise expressed in tangible form. Copyrighted works in the form of intellectual property that can be registered for legal protection, such as literary, artistic, scientific, performance, cassettes, audio-visual broadcasting, scientific discoveries, industrial design, trademarks, business names, etc.

Copyright Holder is the creator as the owner of the Copyright, the party who receives the right legally from the Creator, or another party who receives further rights from the party who received the right legally.

This research is expected to produce a batik standardization model for marketing empowerment so that batik artisans, either as individuals, and / or business entities can continue to produce batik and carry out their marketing well.

Research Methodology And Work Creation

This research basically covers two fields, namely art and marketing. Rohidi (2011:2) said that art data is usually data in the form of visual, kinetic, and auditory or a combination of two or all three that reflect the elements of art and aesthetic principles that underlie it. The data is referred to intraestetic data and in its disclosure as facts accompanied by more descriptive explanations. The data relating to marketing can be presented in quantitative and qualitative forms.

The method used in this research is descriptive qualitative method and direct exploration / practice. Reports are described or presented in descriptive form. The data obtained in this study, are through field / direct practice (researchers are batik artisans and batik marketing actors), in-depth observations, and literature studies. Data is also obtained through internet sources. The direct practice method is carried out to find out problems directly in the sale of batik products. Karsam (as the research team) is the owner of Keyna Galeri in Ploso, Jombang, East Java, which is engaged in batik production and marketing.

Results And Discussion

Batik standardization as a form of empowerment in the marketing process can be categorized into the Business Model Standardization. The Indonesian Academy Franchise explains that the Business Model Standardization can be divided into 2 (two) parts. They are Standardization Form and Standardization Process.

Standardization of forms in general can be:

1. Design

2. License and legality 
3. Operasional equipment

4. The equipment and attribute of building/shop

3. Building size

4. Location criteria

5. Anything needed before running a business

Process Standardization is generally divided into 3 processes, namely:

1. Marketing process includes promotion, branding, and sales.

2. Operational process includes production, customer acceptance, service, transactions, and maintaining customer relationships.

3. The administrative and financial management processes include HRD, secretarial, and general affairs.

After having standardized processes and standardized forms, the next step is to arrange guidelines:

1. Guidelines for written processes and procedures

2. List of equipment and tool

3. Shape drawing

The batik standardization model for the marketing process is part of the form standardization model and Process Standardization model. The standardization model can be carried out as follows:

\subsection{Organizational / Association / Group Formation Process}

In the quality assurance process, it is necessary to have a body or organization that handles the quality assurance of a product or service. For example: in Surabaya, there is an organization called KIBAS (Surabaya Batik Association). KIBAS is a group / container of lovers / users of batik. One of the work programs of KIBAS is holding batik exhibitions together at the provincial level in East Java. KIBAS members consist of various batik craftsmen from East Java, such as Tuban, Lamongan, Mojokerto, Sidoarjo, Surabaya, Pamekasan, and others. The benefit gained from this activity is the exchange of knowledge in the batik production process. They can compare the quality of the work produced between each other, so they will automatically improve the quality of their products.

Apart from KIBAS, in East Java there is also formed a professional institution, namely East Java Batik Artisan Association (APBJ). This institution can facilitate public testing or feasibility testing (feasibility study) of a batik product to be mass produced. Apart from it, this association has the right to test the competence of batik artisans. Those who pass the test will get Professional Certification. In addition, this association in its work program is almost the same as KIBAS too, but in organizing exhibitions can be followed by holding a seminar. A seminar which is allowed to do the feasibility testing of a product, so that it can be a mass produced.

Specifically to find out the feasibility of a batik product in order to meet the standardization of batik "INDONESIA batik, then the product must be tested in a laboratory. The organization handling this laboratory testing in Indonesia is managed by Balai Besar Kerajinan dan Batik Yogyakarta. (BBKBY).

\subsection{The Arrangement of Standard Operating Procedure (SOP)}

After the organization dealing with batik production, batik management, and batik preservation was formed, it is necessary deemed to prepare written guidelines and governance in the form of Standard Operating Procedures (SOP). SOP is a regulation made in order to facilitate the work done (Djessus).

In the industrial and corporate world and SOPs are needed, so that every employee, head of department and company leadership know the direction and objectives to be achieved. A good SOP can produce good results. To obtain a good SOP in batik organizations / associations, it must be carefully formulated together to achieve a common goal.

\subsection{Licensing or Legality (Trademark and SIUP)}

A person whether in the form of an individual or business entity that runs a trade is expected to have a business identity. This business identity takes the form of a Trademark.

The Directorate General of Intellectual Property Ministry of Law and Human Rights of the Republic of Indonesia explains that a Mark or Trade Mark is a sign or symbol which is manifested in a graphic form in the form of a name, word, picture, logo, letter, arrangement of colors, numbers, in the form of two (2) dimension and / or three (3) dimensions can be in the form of sound, holograms. Brands can also be made with a combination of two (2) or more elements of names, words, images, and others. This mark is to distinguish goods and / or services produced by persons or legal entities in the trading of goods and / or services.

Brand usage functions, namely:

1. Identification of one's production results. This sign can distinguish between the results of a person's production or several people with one another.

2. A tool or media for promotion

3. a guarantee for the quality of goods and / or services 
4. Mark of origin of goods / services produced.

Whereas, the functions of a trademark registration are:

1. Proof of ownership which is entitled to the registered mark

2. A basis for refusal of the applicant to the same Mark as a whole or the same in principle for similar goods / services and to prevent others from using the Mark.

After an individual or business entity that runs a trade has a trademark, they must register their business license.

All people who are conducting trading business, trading businesses in the form of individuals or business entities, they must legalize or legalize their business before the law. This business is to get a permit in running a trading business, in the form of a Trading Business License or SIUP.

Small or large scale businesses are required to make SIUP as proof of business legality. This can expedite the trade process to achieve shared interests, both individual interests, group interests, and government interests.

Utami (2020, 6 January) explained that to obtain SIUP, certain administrative requirements were needed. After the requirements are complete, you can register your products at the Trade Office at the city, district or at the Integrated Licensing Service Office.

In the administration of SIUP, administrative requirements are made that will later relate to government taxes. One of the conditions is filling the form by stating the number written down in the National Identity Card (e-KTP) and the Taxpayer Identification Number (NPWP). This NPWP is related to withholding tax every time you make a product sale. By paying taxes to the government, the government is expected to be able to manage, monitor and protect the trade or marketing system in Indonesia. For example: the government provides financial assistance for Community Activity Units (UKM) to manage their businesses and vice versa the government can cancel its SIUP, if there are any Community Activity Units that violate trade laws.

At the current condition of the Indonesian government, which has many corrupt people, the licensing system to obtain SIUP must be done online. With this online method, the government can easily manage finances from registration revenues or taxes issued by someone.

Related to SIUP, in this research, the researcher proposes that SIUP is not only in the form of License but also in the form of a certificate. This certificate is packed up properly and must be sticked or tapped in the shop wall / stall wall. This will make it easier for the government to find out whether a business has SIUP or not when the government conducts an inspection. For those who do not have the certificate, the business license can be canceled / revoked.

Types of SIUP according to Utami (2020, 6 January) SIUP is divided into four (4) types, namely:

1. Micro SIUP, it is a SIUP given to business owners who have capital assets of between Rp. $50.000 .000-$ 500.000 .000

2. Small SIUP, it is a SIUP given to business owners who have capital assets of between Rp. $50.000 .000-$ 500.000 .000

3. Medium SIUP, it is SIUP given to business owners who have a capital of between Rp. 500.000.000 - 10 . milyar

4. Large SIUP, it is a SIUP given to business owners who have capital assets of more than Rp. 10 milyar

\subsection{Quality Assurance}

In Jurnalmanejem.com (2019, July 11), it was explained that customer satisfaction is the key to success in creating customer relationships that affect the company's success in the long run. The level of customer satisfaction is determined by the quality of products and services. Quality products and services can cause competition in trade. quality levels which meet customer's expectations can produce high satisfaction.

In 2015 the Indonesian government conducted free trade both at the ASEAN and international levels. Even in the State itself, it could feel how free affected the state. Various people can easily trade with an online sales system. It's as if they are trading without government control. This event took place naturally, those who could not carry out quality assurance or could not manage their business properly, they experienced bankruptcy. Even the capitalist system will occur naturally. Therefore we need a governance and product quality assurance.

Quality assurance covers many things, including quality assurance of services, design, infrastructure, and so forth. Specifically in this study is product quality assurance in the form of batik cloth.

The above writing has explained that one of the organizations which can assure the quality of batik products in Indonesia is BBKBY. One of the activities carried out by BBKBY is conducting a laboratory testing to determine the quality of batik cloth. From the results of this laboratory, a standard batik "INONESIA" batik will be obtained, in the form of Batik Tulis, Batik cap or Batik Kombinas. This step can be followed up by getting the batik label, which is "batikmark".

Up to now, there are 3 types of Indonesian batik products which have been recognized or standardized. They are Batik Tulis, Batik cap and Batik Kombinas. Meanwhile, batik on the market commonly referred to Batik cap, batik jumputan, eco print, etc. have not been standardized. The characteristics of Batik Tulis, Batik cap, and Batik 
Kombinas, are explained in Table 1-3.

Table 1. Charateristic of Batik Tulis

No Indicator Observed Charateristic

1 Smell Wax Smell

2 Process and Physical a. Motifs on the frabric whether can be repeated or not charateristic

b. The streaks of the used wax are not always exactly the same on every written klowong (the main motif design) line, the repetition of the motif and the connected motif

c. There is a color seepage caused by the thinness of wax streaks, the braoken wax irregularity and the edges of the wax soles

d. the wax soles penetrating behind the cloth are not exactly the same

e. The number, size, distance, and shape of the Isen Shapes (filler motif of klowong) are not always the same

f. The results of the crumbling process are always obtained broken irregularity

g. The results of the crushing process are always obtained broken irregularity wax

Table 2. The Charateristics of Batik Cap

\begin{tabular}{lll}
\hline No & Indicator Observed & Charateristics \\
\hline 1 & Smell & Wrocess and physical \\
charateristic & a. The result of batik is repeated the same and or there is a shifting on every \\
repetition. & b. There is a color seepage caused by irregularity of broken wax friction and at \\
the edge of the wax sole. \\
c. the wax soles penetrating behind the cloth are the same \\
d. The number, size, distance, and shape of the Isen Shape ((filler motif of \\
klowong) are not always the same \\
e. The results of the crumbling process are always obtained broken irregularity \\
f. The result of tembokan (covering the white cloth by using hot wax) is \\
obtained broken irrigularity wax \\
g. There are soles as a sign of stamping the cloth with or without penitis
\end{tabular}

Table 3. The Charateristics of Batik Kombinasi

\begin{tabular}{|c|c|c|}
\hline No & Indicator Observed & Charateristics \\
\hline 1 & Smell & Wax smell \\
\hline \multirow[t]{8}{*}{2} & Process and the & a. Motifs on the frabric whether can be repeated or not \\
\hline & physical charateristcs & b. Rapot (the result of) Batik Kombinasi is repeated the same on every repetition. \\
\hline & & $\begin{array}{l}\text { c. The streaks of the used wax are not always exactly the same on every written } \\
\text { klowong (the main motif design) line, the repetition of the motif and the } \\
\text { connected motif }\end{array}$ \\
\hline & & $\begin{array}{l}\text { d. There is a color seepage caused by the thinness of wax streaks, the braoken } \\
\text { wax irregularity and the edges of the wax soles }\end{array}$ \\
\hline & & e. . the wax soles penetrating behind the cloth are not exactly the same \\
\hline & & $\begin{array}{l}\text { f. The number, size, distance, and shape of the Isen Shape (filler motif of } \\
\text { klowong) are not always the same }\end{array}$ \\
\hline & & $\begin{array}{l}\text { g. The number, size, distance, and shape of the Isen Shape (filler motif of } \\
\text { klowong) are the same }\end{array}$ \\
\hline & & $\begin{array}{l}\text { h. The results of the crumbling process are always obtained broken irregularity } \\
\text { i. The result of tembokan covering the white cloth with hot wax) is obtained } \\
\text { broken irrigularity wax }\end{array}$ \\
\hline
\end{tabular}

Picture 4 is Flow Chart low of submitting batikmark label "batik INDONESIA" 


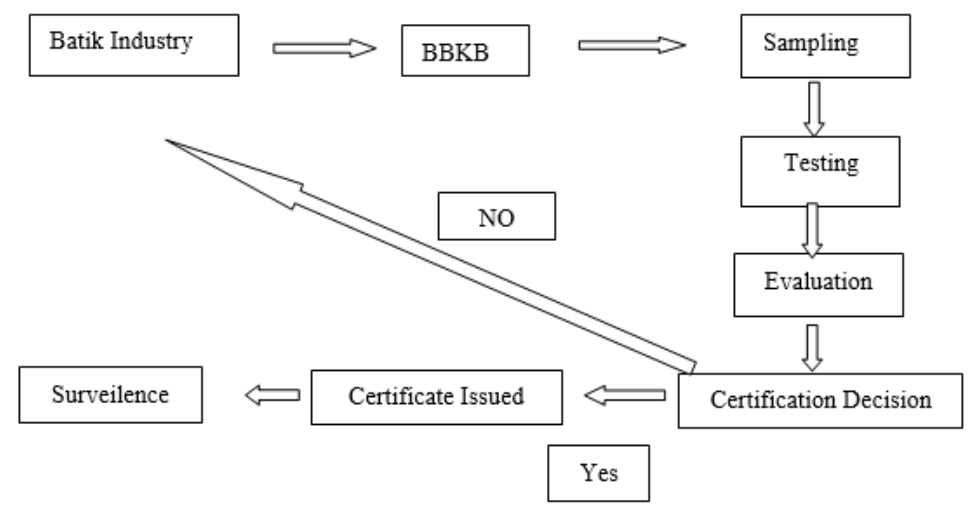

Picture 4. Flow chart of submitting batikmark label "batik INDONESIA" (Source: Karsam, 2019)

The flowchart of submitting "batik INDONESIA" batikmark label begins with the batik industry/batik artisans submitting an application to BBKBY. Then BBKY appointed a laboratory / testing laboratory. The testing laboratory will take samples tested and evaluated. If the product tested meets the standard, a certificate will be issued and the next step will be to supervise the products. whereas, if the product does not pass the laboratory testing, the batik product will be returned to its owner/industry for repairing and then, resubmitted.

\subsection{Identification / Label Attachment}

It has been explained above that after batik products are tested through a laboratory by BBKBY, that batik will be known for its suitability or quality as Batik Tulis, Batik Cap, and Batik Combination . After this process is passed, it is expected that batik artisans will register their batik in order to obtain the batik label, namely batik mark "batik INDONESIA". Batikmark is a sign which shows the identity and characteristics of Indonesian-made batik consisting of 3 types namely Batik Tulis, Batik Cap dan Batik Kombinasi dan batik Combination).

The purpose of labeling batik products (Nugroho, 2017), namely:

1. Giving trust or certainty to consumers so they are not wrong in choosing batik.

2. Providing quality assurance to consumers about Indonesian batik.

3. It is legally able to protect and preserve Indonesian batik products related to Intellectual Property Rights (IPR) from the threat of plagiarism in the field of IPR or trade in the country and abroad.

4. This label can make consumers find out or recognize that the product is the original Indonesian batik.

5. The capability of providing trust, and consumer convenience on the quality and image of Indonesian batik in the international community

In order to obtain a certificate of the usage of batikmark both individuals and Batik entities required a condition, which are:

1. Have a registered brand

2. Meet SNI requirements including the shrunken nature, cloth size, color fastness from washing and color rub resistance Memenuhi

3. Meet SNI standards as Batik Tulis, Batik Cap and combination batik combination

Karsam (2019: 187-190) also explained the procedure in obtaining a Batikmark certificate are:

1. The company must submit a request letter to BBKBY attached with the company profile.

2. BBKBY can carry out its own testing or appoint a testing laboratory.

3. A testing laboratory takes samples in the nearest places

4. The results should be reported to the head of BBKBY

5. Batik that passes the laboratory testing will receive a Batikmark Use Certificate by BBKBY

The detail form of the batikmark label, such as; picture 1 , picture 2 , and picture 3 . The size or conditions of the label are:

1. Length $6.5 \mathrm{~cm}$ dan width $2 \mathrm{~cm}$

2. The word "batik INDONESIA". The word "batik" uses lowercase letters and INDONESIA capital letters.

3. The word "batik", it is written specifically. The letter "b" uses dots called cecek, the letter "a" is in the form of a tendril, the letter " $\mathrm{t}$ " is in the form of a flower; letter " $\mathrm{i}$ " is dot/called cecek; the letter " $\mathrm{k}$ " is in the shape of a cloud.

4. The words BATIK TULIS and BATIK CAP use arial font with a size of 7 pt. Whereas, BATIK CAP- TULIS uses arial font with a size of $8 \mathrm{pt}$.

5. The number of Batikmark Certificate user is printed

6. Mark batik label made in the form of writing / border / embroidery / stamp.

7. Basic black color is used. The writing of batik uses gold for the type of batik tulis, white for the type of batik 
cap, and silver for the type of batik kombination.

8. Label's Numbering System are:
a. 2 digits after the province code
b. 2 digits in the middle of registration year
c. 3 digit after serial number
d. Size batikmark label "batik INDONESIA" on a scale of $1: 3.25$

\subsection{Socialization dan promotion}

Socialization is the process of learning or conveying information to individuals related to values and rules in the community to carry out, create attitudes, and behavior of individuals in accordance with the values and norms imposed. In this research, the meaning of socialization is it is mandatory for the government to convey information about "batik INDONESIA" batik which is marked with a batikmark label or label. This socialization can be done in various ways, such as; through the Office of the Ministry of Industry and Trade at the city/district level, provincial level, and others. The means that can be used for this socialization, can be through news on TV, the web, YouTube, Instagram, government regulations, and etc.

The purpose of this socialization is for individuals or Indonesian people to know "INDONESIA batik" batik in the hope that Indonesian individuals or people love domestic products and not choose the wrong type and quality of batik when buying batik cloth.

Promotion is a communication which aims to inform a company's product to the public.

One of the strategies in developing a business / marketing is promotion. Mayasari (2009) described several forms of promotion that can be done in marketing, namely::

1. Personal Selling, it is a form of two-way communication between the seller and the buyer or prospective buyer to offer the product

2. Advertising, it is in the form of advertising media (advertisements, posters, and the like) to introduce or promote company products to the wider community / consumers

3. Sales Promotion, it is a form of promotion carried out by means of exhibitions or certain events, so that consumers quickly know the products being marketed.

4. Publicity, it is namely establishing good relations with the public, maintaining the company's image and its products.

\subsection{Government Supervision, Entrepreneur/Private Organization.}

The Government Regulation in lieu Law Number 8 of 1962 concerning Trading of Goods under Supervision [21]. Article 5 paragraph (1) With or based on a Government Regulation it can be stipulated that the trade in goods under supervision of:

a. It can be controlled and managed by the authorities;

b. It can be controlled and endeavored by the authorities along with private entrepreneurs / organizations;

c. It can be controlled and managed by entrepreneurs / private organizations.

Based on the aforecited Law, it is necessary to have inherent and continuous supervision towards either individuals, and or business entities which run trade. For those that get caught in violation of the applicable Trade Law, theeir SIUP or business license certificates are revoked and recieved sanction. This is done so that the marketing / trade process in Indonesia runs smoothly.

Based on the discussion above, it can be described that batik standardization as an empowerment model for batik artisans for marketing, as shown in the following picture. 


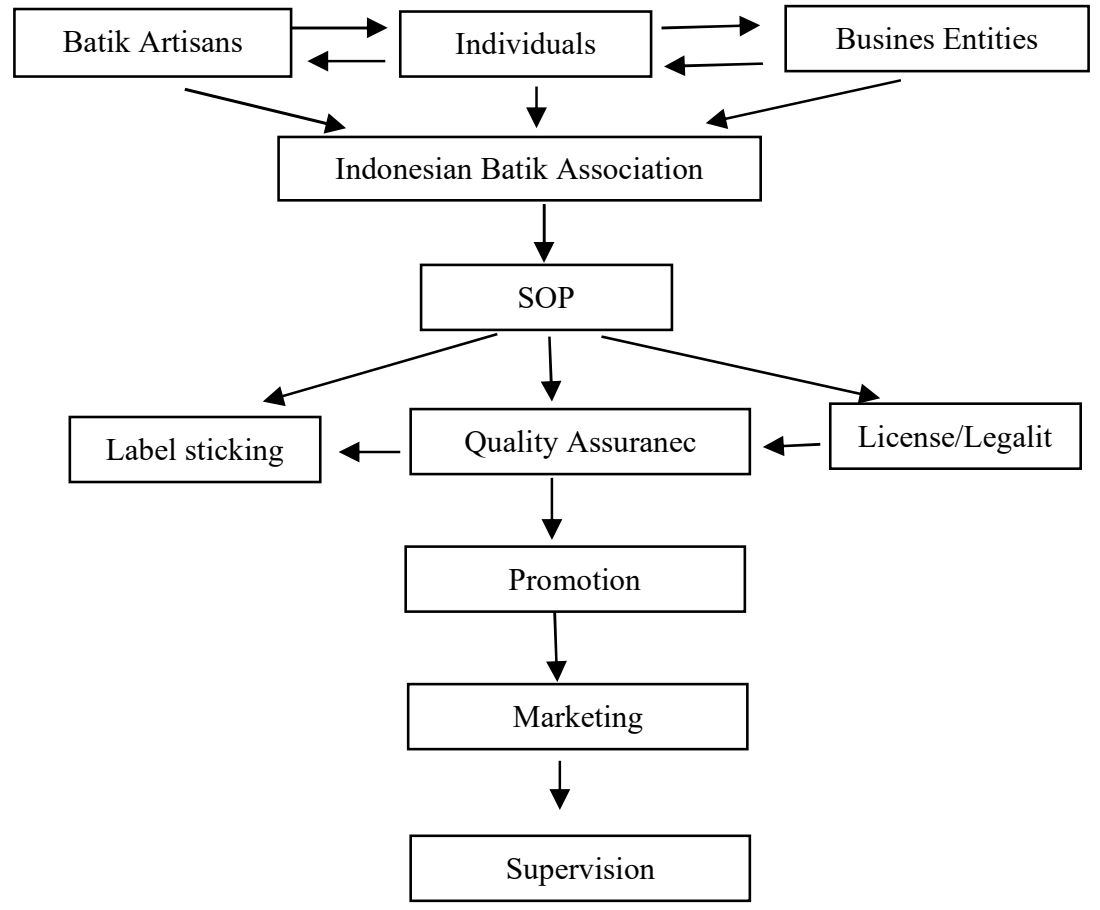

Picture 5. Batik standardization as an empowerment model for batik artisans to marketing

\section{CONCLUSION AND SUGGESTION}

\section{A. Conclusion}

This research aims to produce batik standardization as an empowerment model for batik artisans, individuals, or business entities for marketing. Either individual. Either individuals or business entities. The results of this study are the formation of batik association as a discussion forum in Indonesia concerning about knowledge exchange for the development and preservation of batik. Another result of this study to have a proper knowledge concerning trademark registration, trademark functions, SIUP Management, batik standardization, Management of Label batikmark "batik INDONESIA". Besides, it obtains data which shows that batik that there are 3 types of batik that meets SNI. They are batik tulis, batik cap, and batik kombinasi. It obtains a knowledge related to the shape and size of "batik INDONESIA" batikmark label which should be attached to every batik cloth sold.

In order to get batik label, batik product must pass the feasibility testing from BBKBY. Apart from it, to make sure label management and marketing run smoothly, batik products should not be a copy someone's design or not being copied by others, we should have HKI Certificate. Indonesian government supervision towards the marketing process must be carried out continuously and the enforcement and enforcement of the Indonesian trade law must also be carried out, so that the marketing process carried out by batik artisans, individuals, or business entities runs smoothly. The Indonesian Government Supervision towards marketing process must be carried out continuously and the curb and enforcement of Indonesian trade law must also be carried out, so that the marketing process carried out by batik artisans, individuals, or business entities run smoothly. The aim of this research is to produce a batik standardization model for marketing empowerment so that batik artisans in Indonesia, both individuals, or business entities can carry out batik production and marketing smoothly.

\section{B. Suggestion}

1. As batik producers or people who produce batik, Batik Artisans are expected to continue creating new motifs and being taken care of their copyrights.

2. Batik artisans in Indonesia are expected to establish a batik association in a higher level, not only in a district level but also in the provincial and state levels.

3. Individuals and / or business entities must register their trademarks and administer SIUP.

4. Individuals and or business entities must comply with the applicable trade laws in Indonesia.

5. The government is expected to revise or improve the Trade Laws.

6. Trade certificate assurance for the store or stalls that meet the requirements and the trade certificates are revoked when the owner of the store violates the laws.

7. Supervision of marketing / trade is carried out continuously along with the government, entrepreneurs / private 
organizations.

\section{References}

Badan Standardisasi Nasional. (2014). Pengantar Standardisasi. (Ed-2). Jakarta: Badan Standardisasi Nasional.

Balai Besar Kerajinan dan Batik. (2017, 14 September). Bagaimana Cara Membedakan Kain Bermotif dan Kain Batik?. Yogyakarta: Intranet BBKB, Kementerian Perindustrian Republik Indonesia.

Bramantijo, M Junaidi Hidayat. Karsam dan Mahjudin. 2017-2018. Laporan Penelitian Strategi nasional Institusi (Dana Ristekdikti). "Pengembangan Desain Motif Cocohan Dan Desain Kemasan Pada Batik Gedhog Tuban Sebagai Upaya Revitalisasi Dan Meningkatkan Daya Saing Produk Ukm".

Direktorat Jenderal Kekayaan Intelektual Kementerian Hukum dan HAM Republik Indonesia. (tth.). Pengenalan Merek. https://dgip.go.id/pengenalan-Merek. Diakses tanggal 14 Februari 2020.

Djessus, Ahmad. (2018, 25 Sep). Pengertian SOP - Standard Operating Procedures. Apitu Indonesia (Perkumpulan Praktisi Pendingan dan Tata Udara Indonesia). https://apitu.org/pengertian-sop-standardoperating-procedures/. Diakses tanggal 13 Februari 2020.

Fahrudin, Imam. (2018, 15 Mei). Mengenal Pengertian Standardisasi, Tujuan serta Manfaatnya. https://www.caraprofeser.com/mengenal-pengertian-standarisasi/. Diakses tanggal 10 Januari 2020.

Franchise Akademy Indonesia. (2020, 12 Februari). Standarisasi Bentuk dan Standarisasi Proses. http://franchiseacademyindonesia.com/. Diakses tanggal 20 Januari 2020.

Hari, Y., Dewi, L. P., Santi, C., \& Sembiring, M. J. (2018). Improving Financial Marketing And Accountability With Technology Penetration For The Bag SMEs Community In Gresik, Jawa Timur. Advances in Social Sciences Research Journal, 5(10).

Jawa Pos. 2020. Produknya Mirip, Dua Pabrik Bak Mandi Saling Gugat Desain. Kamis, 30 Januari 2020.

Jurnalmanejemen.com. (2019, 11 Juli). Manajemen Mutu : Pengertian, Tujuan, Proses, Manfaat Disertai ISO. https://jurnalmanajemen.com/manajemen-mutu/. Diakses tanggal 20 Januari 2020.

Karsam. (2014). Pelestarian dan Ekspansi Pasar Batik Tulis Gedhog Tuban di Era Globalisasi. Jurnal Budaya Nusantara "Budaya Adiluhung". Vol. 1 No. 1 (Juni 2014): 41-53.

Karsam. (2019). Batik Dari Masa Keraton Hingga Revolusi Industri 4.0. Surabaya: CV. Revka Prima Media.

Mayasari, Mukarromah Dian. (2009). Strategi Pemasaran Pada Pt. Batik Danar Hadi Di Surakarta. Surakarta: Program Diploma III Manajemen Administrasi Fakultas Ilmu Sosial Dan Ilmu Politik Universitas Sebelas Maret.

Nugroho, Adi. (2017, 14 November). Lebelisasi Batikmark “batik INDONESIA”. Yogyakarta: Balai Besar Batik Indonesia, Kementerian Perindustrian Republik Indonesia.

Nurmayanti. (2014, 11 Februari). Pengusaha Sebut Undang-Undang Perdagangan Masih Banyak Kekurangan. https://www.liputan6.com/bisnis. Diakses tanggal 4 Februari 2020.

Peraturan Pemerintah Pengganti Undang-Undang Nomor 8 Tahun 1962 tentang Perdagangan Barang-Barang Dalam Pengawasan.

Rai Utama, I Gusti Bagus. (2017). Pemasaran Pariwisata. Yogyakarta: CV. Andi Offset

Rohidi, Tjetjep Rohendi. (2011). Metodologi Penelitian Seni. Semarang: Cipta Prima Nusantara.

Sonalia, Devi dan Musa Hubeis. (2013). Pengendalian Mutu Pada Proses Produksi Di Tiga Usaha Kecil Menengah Tahu Kabupaten Bogor. Jurnal Manajemen dan Organisasi Vol IV, No 2, Agustus 2013. Departemen Manajemen, Fakultas Ekonomi dan Manajemen Institut Pertanian Bogor.

Standar Nasional Indonesia. (2016). Surat Keputusan Kepala Badan Standardisasi Indonesia Nomor 188/KEP/8/2016 tentang Penetapan Revisi 3 (tiga) Standar Nasional Indonesia. Jakarta.

Utami, Novia Widya. (2020, 6 Januari). Panduan Membuat SIUP (Surat Izin Usaha Perdagangan). Jurnal. https://www.jurnal.id/id/blog/panduan-membuat-siup/. Diakses tanggal 1 Januari 2020.

Widiana, Muslichah Erma, Kusni Hidayati, dan Karsam. 2019. Teorik dan Empirik Strategi Pemasaran (Beserta Studi Kasus Permasalahan Perusahaan Swasta Di Jawa Timur). Mimika Baru, Papua: Penerbit Aseni. 